\title{
LANDSCAPE STRUCTURE IN THE NORTHERN COAST OF PARANÁ STATE, A HOTSPOT FOR THE BRAZILIAN ATLANTIC FOREST CONSERVATION1
}

\author{
Érico Emed Kauano ${ }^{2}$, José Marcelo Domingues Torezan ${ }^{3}$, Fernanda Cristina Gil Cardoso ${ }^{4}$ e Márcia \\ Cristina Mendes Marques ${ }^{4}$
}

\begin{abstract}
The "Serra do Mar" region comprises the largest remnant of the Brazilian Atlantic Forest. The coast of the Paraná State is part of the core area of the "Serra do Mar" corridor and where actions for biodiversity conservation must be planned. In this study we aimed at characterizing the landscape structure in the APA-Guaraqueçaba, the largest protected area in this region, in order to assist environmental policies of this region. Based on a supervised classification of a mosaic of LANDSAT-5-TM satellite images (from March 2009), we developed a map (1:75,000 scale) with seven classes of land use and land cover and analyzed the relative quantities of forests and modified areas in slopes and lowlands. The APA-Guaraqueçaba is comprised mainly by the Dense Ombrophilous Forest (68.6\% of total area) and secondary forests $(9.1 \%)$, indicating a forested landscape matrix; anthropogenic and bare soil areas $(0.8 \%)$ and the Pasture/Grasslands class (4.2\%) were less representative. Slopes were less fragmented and more preserved (96.3\% of Dense Ombrophilous Forest and secondary forest) than lowlands $(71.3 \%)$, suggesting that restoration initiatives in the lowlands must be stimulated in this region. We concluded that most of the region sustains well-conserved ecosystems, highlighting the importance of Paraná northern coast for the biodiversity maintenance of the Atlantic Forest.
\end{abstract}

Keywords: APA of Guaraqueçaba, Land use and Fragmentation.

\section{ESTRUTURA DA PAISAGEM DO LITORAL NORTE DO PARANÁ: UM HOTSPOT DE CONSERVAÇÃO DA MATA ATLÂNTICA BRASILEIRA}

\begin{abstract}
RESUMO - A região da Serra do Mar compreende o maior remanescente da Floresta Atlântica brasileira. A costa do Estado do Paraná faz parte desta área, onde ações para a conservação da biodiversidade devem ser planejadas. O objetivo deste estudo foi caracterizar a estrutura da paisagem na APA de Guaraqueçaba, a maior área protegida no litoral Norte do Paraná, a fim de subsidiar políticas ambientais para a região. Com base em uma classificação supervisionada de um mosaico de imagens de satélite LANDSAT-5-TM (de março de 2009), foi produzido um mapa (escala 1:75.000) com sete classes de uso e cobertura do solo e analisada a quantidade relativa de florestas e áreas modificadas nas encostas e planícies. A APA de Guaraqueçaba compreende, principalmente, a Floresta Ombrófila Densa (68,6\% da área total) e florestas secundárias (9,1\%), indicando uma matriz de paisagem florestada; as classes "áreas antrópicas" e de "solo exposto" (0,8\%) e "pastagens e campos" (4,2\%) foram menos representativas. As encostas são menos fragmentadas e mais preservadas (96,3\% de Floresta Ombrófila Densa e florestas secundárias) que a planície (71,3\%), sugerindo que iniciativas de restauração devem ser estimuladas nesta última. Pode-se concluir que a maior parte da região de estudo sustenta ecossistemas bem preservados, o que destaca a importância do litoral Norte do Paraná para a manutenção da biodiversidade da Floresta Atlântica.
\end{abstract}

Palavras-chave: APA de Guaraqueçaba, Uso do solo e Fragmentação.

\footnotetext{
${ }^{1}$ Recebido em 23.03.2012 aceito para publicação em 04.06.2012.

${ }^{2}$ Instituto Chico Mendes de Conservação da Biodiversidade, Floresta Nacional do Amapá. E-mail: <erico.kauano@ icmbio.gov.br>.

${ }^{3}$ Universidade Estadual de Londrina, Centro de Ciências Biológicas, Departamento de Biologia Animal e Vegetal. E-mail: <torezan@uel.br>.

${ }^{4}$ Universidade Federal do Paraná, Setor de Ciências Biológicas, Departamento de Botânica. E-mail: <fernanda.g.cardoso@gmail.com> e $<$ mmarques@ufpr.br>.
} 


\section{INTRODUCTION}

The Brazilian Atlantic Forest sustains one of the highest biodiversity and endemism rates in the world, but, conversely, it has also been the setting of a long degradation history (DEAN, 1995), resulting in a highly fragmented and endangered biome (MYERS et al., 2000; GALINDO-LEAL; CÂMARA, 2003). Recent broad scale estimates show that only 11 to $16 \%$ of the original cover of this biome still remains, of which only $9 \%$ are in protected areas and only $1 \%$ are original primary forest (SILVA; CASTELETI, 2003; RIBEIRO et al., 2009). The forest remnants are, in general, small-sized ( $<50$ ha) and considerably far apart from each other, which highly affect species richness and composition of multiple taxa, as well as ecosystem processes (LIEBSCH et al., 2008; LOPES et al., 2009; METZGER et al., 2009; VIEIRA et al., 2009).

The high variation in Atlantic Forest elevation, physiognomy and land use history (DEAN, 1995; OLIVEIRA-FILHO; FONTES, 2000; MARQUES et al., 2011) resulted in differences in fragmentation rates and conservation status. From the eight different ecoregions, the Serra do Mar corridor, distributed in the Brazilian states of Rio de Janeiro, São Paulo, Paraná and Santa Catarina, is the most preserved region, where $36.5 \%$ of the original forest is remaining (RIBEIRO et al., 2009). Furthermore, $25.2 \%$ of the remaining forests are in protected areas (RIBEIRO et al., 2009), making this area the most important biodiversity shelter of Atlantic Forest in Brazil.

In Paraná State, the Atlantic Forest biome originally covered $97 \%$ of the state area, but, currently, only $10 \%$ of Atlantic Forest still remains, mainly associated to the Serra do Mar corridor, in the northern coast of the state (SOS MATA ATLÂNTICA; INPE, 2008). In this region, several protected areas were established over the last decades in order to guarantee the biodiversity conservation (GRISE et al., 2009); nevertheless, some areas are still used for farming and pastures (FERRETI; BRITEZ, 2006). The contrast between environmental and social interests has led to increasing levels of degradation of natural resources (BORSATTO et al., 2007). Thus, the accurate measure of the changes in land use and in the landscape dynamics, an important tool for the regional policies of conservation and management (CALEGARI et al., 2010), is urgent for the Atlantic Forest.

Revista Árvore, Viçosa-MG, v.36, n.5, p.961-970, 2012
The aim of this study was to characterize the landscape structure of the northern coast of Paraná, by evaluating the land use and the land cover in the region from images of 2009. We updated previous analyses (IPARDES, 1990; IPARDES, 2001; PROATLÂNTICA, 2001; SCHMIDLIN; BRITEZ, 2002; GRISE et al., 2009) and compared the landscape of the coastal plains (lowlands) with the slopes to assess the amount of forests and disturbed areas, and support the conservation planning and management in this important region of the Atlantic Forest.

\subsection{Study area:}

The study was carried out in the northern coast of Paraná State, which encompasses the Environmental Protection Area of Guaraqueçaba (APA-Guaraqueçaba) together with the Antonina and Laranjeiras River Basins. The area of these two basins corresponds approximately with the area of the APA-Guaraqueçaba (Fig. 1), an environmental reserve established by the Federal Decree 90883 of 1985 (BRASIL, 1985) that aims to protect the Atlantic Forest, the estuarine complex of Paranaguá Bay, the archaeological sites of the region (especially shell middens) and the traditional communities (caiçaras) integrated into the regional ecosystem. Furthermore, it aims to controlling the use of pesticides and other chemicals and to establishing rational criteria for land use in the region. This reserve and other environmental protection areas in the coasts of northern Paraná and southern São Paulo states establish a mosaic of protected areas (BRASIL, 2006).

The region comprises three main geomorphologic units: the coastal plain, the slopes of "Serra do Mar" Mountain Range and the first plateau (Primeiro Planalto) of Paraná (SANTOS et al., 2006). The coastal plain stretches 10 to $20 \mathrm{~km}$ in width and consists of sandy formations, mangroves, terrestrial marshes and alluvial terrains. The altitude varies from around 0 to $10 \mathrm{~m}$ above sea level and may reach $20 \mathrm{~m}$ at the innermost sites. It is bordered by the Atlantic Ocean to the east and the "Serra do Mar" Mountain Range to the west (BIGARELLA, 2001), which consists of a mountain chain with elevations up to $1,800 \mathrm{~m}$ above sea level (ALMEIDA; CARNEIRO, 1998).

The typical climate in the hillsides is mesothermal subtropical humid (Cfa in Köppen's classification), with an average annual temperature between $20.8^{\circ} \mathrm{C}$ and $22^{\circ} \mathrm{C}$. The rainfall is regularly distributed throughout 
the year (between $3300 \mathrm{~mm}$ and $3450 \mathrm{~mm}$ per year), without a defined dry season, and there are occasional frosts. In the coastal plain, the climate is pluvial tropical (Köppen's Aft), with a mean temperature above $18^{\circ} \mathrm{C}$

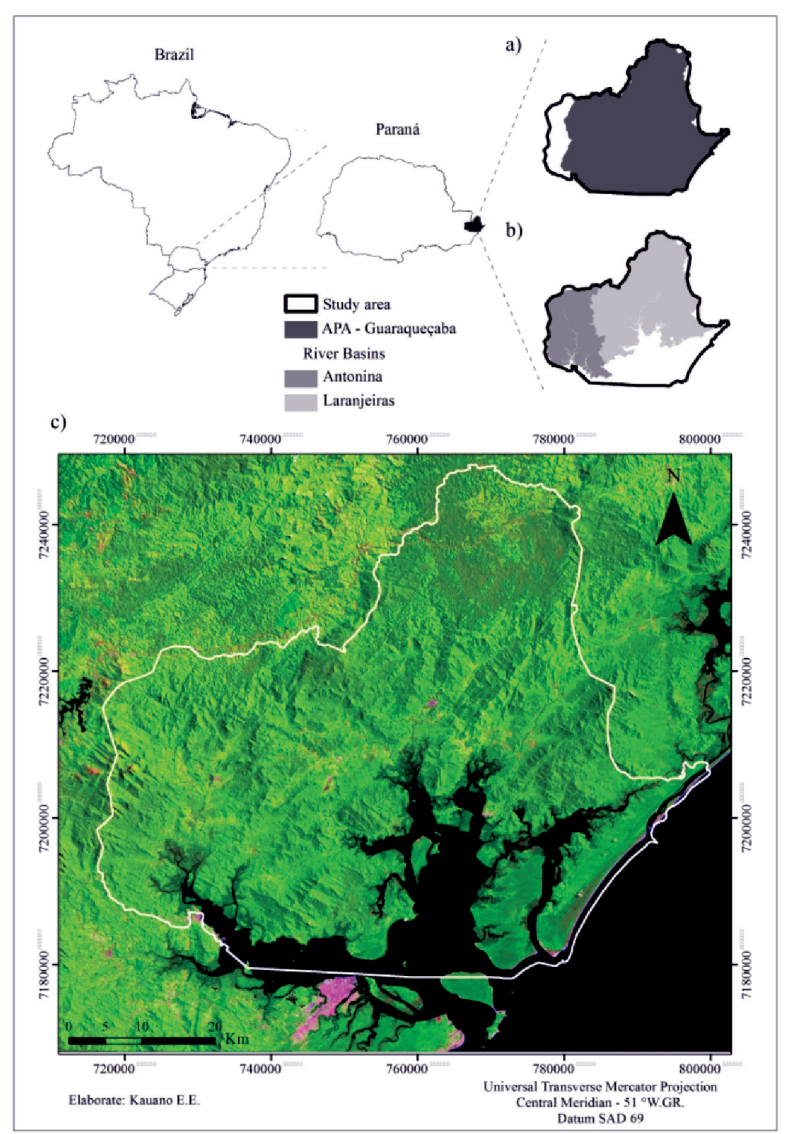

Figure 1 - Study area in the northern coast of Paraná. a) APA-Guaraqueçaba. b) River basins of Antonina and Laranjeiras Bays. c) Satellite image of the study region (RGB composite, bands 5, 4 and 3; from mosaic of LANDSAT-5-TM captured in March, $5^{\text {th }} 2009$, orbit 220 , sections 77 and 78 ). For this study, the river basins and the APA-Guaraqueçaba areas were combined and analyzed together, considering the largest perimeter.

Figura 1 - Área de estudo no litoral Norte do Paraná: a) APA de Guaraqueçaba, b) Bacias hidrográficas das Baías de Antonina e das Laranjeiras e c) imagem de satélite da região de estudo (composição $R G B$ -bandas 5, 4 e 3- a partir de mosaico de imagens LANDSAT-5-TM de 05/03/2009, órbita/ponto 220 77 e 220/78). Para este estudo, as áreas das bacias e a da APA de Guaraqueçaba foram combinadas e analisadas em conjunto, considerando-se o maior perímetro. in the coldest month, permanently humid, frost-free and with an annual rainfall between 2000 and $3500 \mathrm{~mm}$ (FERRETI; BRITEZ, 2006).

The drainage system in the region is dendritic, the main rivers originate on the hillsides, with high slopes and marked valleys. The subsequent river courses, along the plains, usually have large flat valleys and meandering channel patterns (FERRETI; BRITEZ, 2006).

The vegetation is within the Atlantic Forest domain and includes variations of the Dense Ombrophilous Forest (Montane, Sub-Montane, Lowlands and Alluvial) and different types of pioneer formations (fluvial, fluvialmarine and marine influences) (IBGE, 1992; PROATLÂNTICA, 2001; RODERJAN et al., 2002).

\section{MATERIALAND METHODS}

\subsection{Image acquisition and treatment:}

In order to compose the map of the region, we used three different information sources: 1) LANDSAT5-TM satellite images (from $5^{\text {th }}$ March 2009, orbit 220, sections 77 and 78, spatial resolution 30m) obtained from "Instituto Nacional de Pesquisas Espaciais" (INPE, 2009); 2) Twenty-one ortho-rectified SPOT-5 images (from $12^{\text {th }}$ September 2006, spatial resolution $5.5 \mathrm{~m}$ ), provided by the "Instituto Paranaense de Desenvolvimento Econômico e Social" (IPARDES); 3) Vector archives of the Paraná State geomorphology and the APA-Guaraqueçaba perimeter (both at 1:250.000 scale and shapefile format), provided by the "Instituto de Terras, Cartografia e Geociências do estado do Paraná" (ITCG, 2009).

We obtained the study area perimeter by determining the limits of the river basins and combining those to the APA-Guaraqueçaba area. Initially, we produced a mosaic of LANDSAT-5-TM (combination of sections 220/77 and 220/78) and SPOT images. Then, we cropped the image based on the study area perimeter and we used the resulting image (cropped mosaic) as the base image for the subsequent procedures until the creation of the classified image. The LANDSAT images were geometrically corrected (EASTMAN, 2006) from the ortho-rectified SPOT image mosaic.

\subsection{Image classification:}

The map of land use classes was prepared by using supervised classification by the maximum likelihood method, using bands 1, 2, 3, 4, 5 and 7 of the LANDSAT 
TM-5 image mosaic (EASTMAN, 2006) and software ENVI 4.5. For this classification, we created training samples, with polygons manually defined on the base image representing sampling areas of the following classes: Dense Ombrophilous Forest, Lowland Dense Ombrophilous Forest, Initial Secondary Vegetation, Mangrove, Swamp, Pasture/Grassland, Anthropogenic/ Bare soil areas and Water. The samples were arranged by visual interpretation of the LANDSAT-5-TM images RGB composite (bands 5,4,3), with support from fieldwork aided by Google Earth overviews and taking into account the classification proposed by IBGE (1992).

The accuracy assessment of the resulting map was made by means of a confusion matrix, where the percentage of pixels that were correctly classified was calculated, taking the image classified in relation to the samples as a reference and using the Kappa index to evaluate the result (FOODY, 2002). We also applied a Kernel filter ( $3 \times 3$ pixels) to reduce the occurrence of isolated pixels. Furthermore, the classified image was edited manually after the accuracy analysis, to correct any errors of classification.

In order to compare the landscape structure of the coastal plain area (Lowlands) and the "Serra do Mar" Mountain Range and the first plateau of Paraná areas (Slopes), we divided the study area into the compartments "Slopes" and "Lowlands", based on the geomorphologic map of Paraná State (ITCG, 2009)

All maps were done at 1:75,000 scale (GRISE et al., 2009), considering the spatial resolution of $30 \mathrm{~m}$ from LANDSAT-5-TM.

\subsection{Characterization of the landscape structure:}

By using the maps above, we performed a landscape structure analysis by estimating the number of patches, the area (divided by land cover and land use class) and the area proportion of the classes. The indices were produced by using the VLate application (LANG; BLASCHKE, 2007) in ArcGis 9.2.

\section{RESULTS}

The classification process produced an image with eight classes of land cover and land use. The image accuracy, calculated through the confusion matrix between the classifications and the samples, was $92 \%$ (Kappa coefficient $=0.90)$, suggesting a good graphic representation. Although this classification was considered efficient, the edited image resulted in a classification with seven land cover and land use classes (Figure 2) due to class aggregation during the image edition. The seven established classes were (1) Water - Water bodies and sea; (2) Dense Ombrophilous Forest - Original occurrences of Dense Ombrophilous Forest (FOD) in all its sub-formations, secondary forest in intermediate and advanced succession stages and also pioneer formation areas with fluvial influence; (3) Secondary Forest - Secondary succession formations of Dense Ombrophilous Forest in initial stages of succession, in all its sub-formations; (4) MangrovesPioneer forest formations with fluvial-marine influence; (5) Pastures/Grasslands - Pasture, crops, agricultural fields and natural grasslands, (6) Anthropogenic /Bare soil areas - Urban areas, roads, bare soil areas used for agriculture and other areas of bare soil, such as rock outcrops; (7) Beach - Sandy areas in the coastal plain.

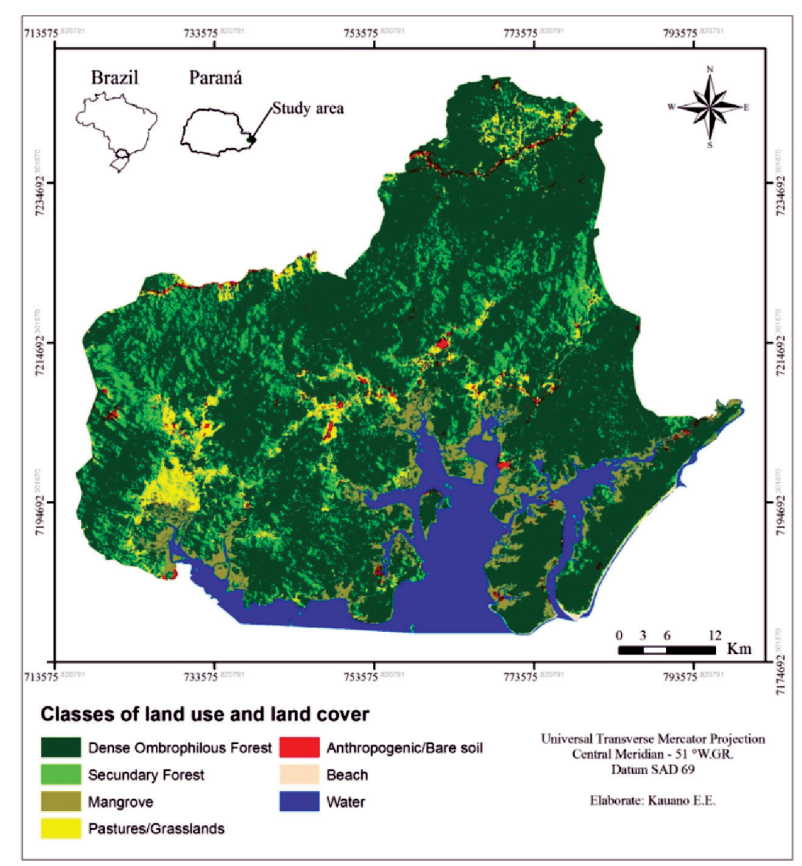

Figure 2 - Map of land use and land cover in the APAGuaraqueçaba, northern coast of Paraná State, Brazil.

Figura 2 - Mapa de uso e cobertura do solo da Área de Proteção Ambiental de Guaraqueçaba, litoral Norte do Paraná, Brasil. 
The characterization of the different land cover and land use classes of the APA- Guaraqueçaba (Table 1) reveals that the Dense Ombrophilous Forest class was the most representative one, covering the greatest portion $(68.6 \%)$ of the total area studied. This type of forest, together with secondary forests $(9.5 \%)$ and mangroves (5.3\%), comprised $83 \%$ of the area. The disturbed and bare soil areas accounted for less than $1 \%$ of the total area and areas of pastures and grasslands comprised $4.2 \%$.

When only terrestrial areas were considered (class Water removed) and the two compartments (slopes and lowlands) were compared, a different distribution of land cover and land use classes was observed (Figure 3, Table 1). The total area of the slopes is approximately twice as large as the lowlands $(207,788.90$ ha and 100,535.27 ha, respectively). The Dense Ombrophilous Forest area in the slopes is almost three times the extent of the corresponding area in the lowlands (Table 1), which also reflects the difference between the total areas of the compartments, although, in proportional terms, this difference is not very pronounced ( $84.7 \%$ and $63.5 \%$, respectively). Considering all forest formations (Dense Ombrophilous Forest and Secondary forest), there are $96.3 \%$ of forest cover on the slope portion and $71.3 \%$ on the lowland portion, revealing a matrix of forested landscape in both areas. The results also indicate a greater suppression of vegetation (resulting from human activity) in the lowlands, since the combination of the classes pastures/grasslands and anthropogenic areas/bare soil corresponds to $9.7 \%$ in the lowlands and $3.7 \%$ in the slopes.

Analyses including only habitat areas (lowland and slope Dense Ombrophilous Forest), showed high frequency of small patches $(<5$ ha), but they represent only $<2 \%$ of the total area (Figure 4$)$. On the other hand, larger patches ( $>1000$ ha) are less frequent $(<2 \%)$, but comprise a larger area $(>68 \%$ of the total; Figure 4$)$, indicating a landscape dominated by continuous forests (Figures 3 and 4).

\section{DISCUSSION}

The landscape analysis of the APA-Guaraqueçaba, northern coast of Paraná State, showed that the region is dominated by forests ( $83 \%$ of the total area), indicating that the matrix may be considered forested and in a good state of conservation. Differences in land use between lowlands and slopes suggest that management initiatives, such as forest restoration, must be encouraged in most fragmented lowland areas.

The Dense Ombrophilous Forest $(68.6 \%$ of the total area) and secondary forests $(9.5 \%)$ were the most representative classes in APA-Guaraqueçaba. Several studies have demonstrated high species richness in areas of primary and secondary forests in the region

(A)

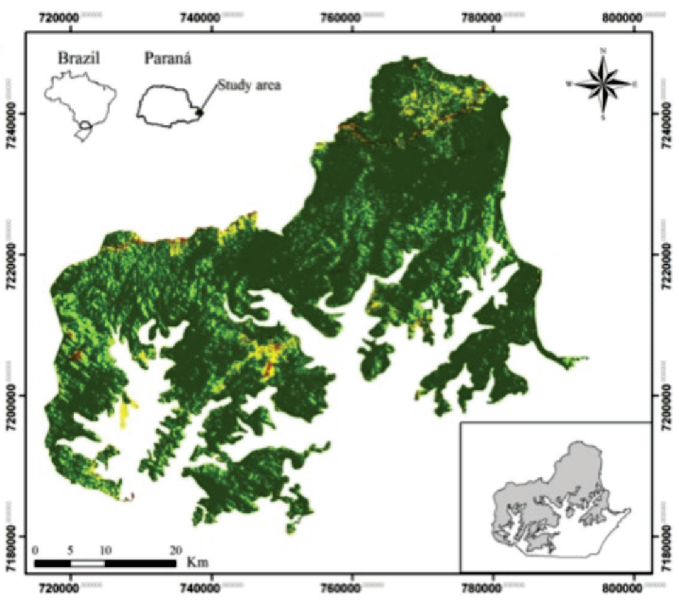

(B)

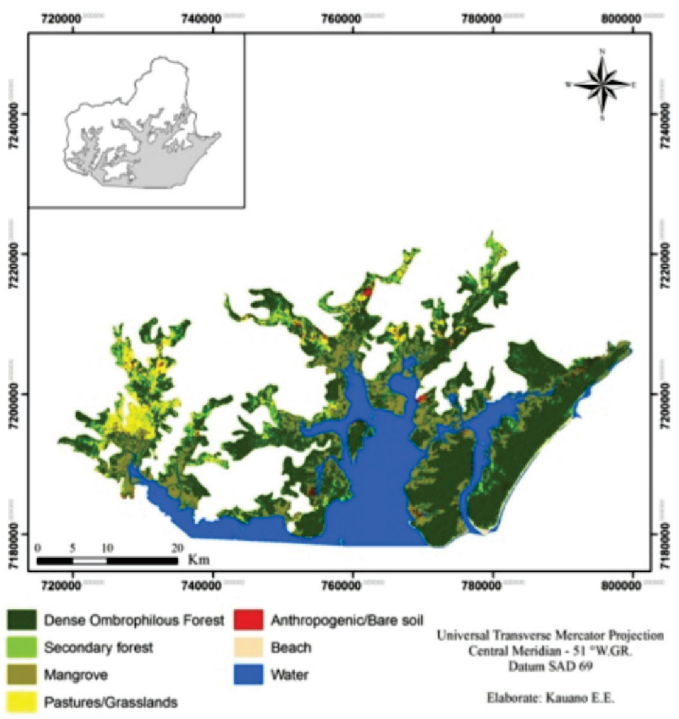

Figure 3 - Map of land use and land cover in the slope (A) and lowlands (B) compartments, APA-Guaraqueçaba, northern coast of Paraná State, Brazil.

Figura 3 - Mapa de uso e cobertura do solo do compartimento Encosta (A) e Planície (B) da Área de Proteção Ambiental de Guaraqueçaba, litoral Norte do Paraná, Brasil.

Revista Árvore, Viçosa-MG, v.36, n.5, p.961-970, 2012 
Table 1 - Land use and land cover classes and landscape parameters in the two compartments (Lowlands and Slopes) in the APA-Guaraqueçaba, northern coast of Paraná State, Brazil.

Tabela 1 - Classes de uso e cobertura do solo e parâmetros da paisagem dos compartimentos Encosta e Planície, da Área de Proteção Ambiental de Guaraqueçaba, litoral Norte do Paraná, Brasil.

\begin{tabular}{lccc}
\hline Land use/Land cover classes & Number of patches & Area (ha) & Proportion (\%) \\
\hline Slopes and lowlands & & & 68.6 \\
Dense Ombrophilous Forest & 1,253 & $239,857.62$ & 9.1 \\
Secondary Forest & 6,625 & $31,873.86$ & 5.3 \\
Mangroves & 349 & $18,350.67$ & 4.2 \\
Pasture/Grasslands & 1,720 & $14,549.37$ & 0.8 \\
Anthropogenic areas/Exposed soil & 868 & $2,898.38$ & 0.2 \\
Beach & 9 & 794.28 & 11.8 \\
Water & 163 & $41,405.32$ & 100 \\
Total & 10,987 & $349,729.50$ & 84.7 \\
Slopes & & & 11.6 \\
Dense Ombrophilous Forest & 351 & $176,050.66$ & 3.0 \\
Secondary Forest & 4,594 & $24,043.79$ & 0.7 \\
Pasture/Grasslands & 909 & $6,268.44$ & 100 \\
Anthropogenic areas/Exposed soil & 384 & $1,426.01$ & \\
Total & 6,238 & $207,788.90$ & 63.5 \\
\hline Lowlands & & & 7.8 \\
Dense Ombrophilous Forest & 902 & $63,806.96$ & 8.2 \\
Secondary Forest & 2,031 & $7,830.07$ & 1.5 \\
Mangroves & 349 & $18,350.67$ & 0.8 \\
Pasture/Grasslands & 811 & $8,280.93$ & 100 \\
Anthropogenic areas/Exposed soil & 484 & $1,472.37$ & 794.28 \\
Beach & 9 & $100,535.27$ & \\
Total & 4,586 & & \\
\hline
\end{tabular}

(GUAPYASSU,1994; LIEBSCH et al., 2007; BORGO et al., 2011). Old growth forests are important source of seeds (LEITÃO et al., 2010) and shelter for animals in the coastal Atlantic Forest (ZWIENER et al., 2012). On the other hand, although secondary forests are a limited habitat for some species (BIHN et al., 2010), some studies have demonstrated that a large number of specialist species can be found in plantations (e. g. cacao) and secondary forests in Atlantic Forest landscapes (PARDINI et al., 2009, FONSECA et al., 2009). Mangroves (5.3\% of the total area) are well conserved in the APA-Guaraqueçaba region. It is possible that these mangroves are one of the most important fragments in Paraná State, highlighting the significance of its preservation (LANA, 2004).

Pastures and grasslands $(4.2 \%)$ and disturbed and bare soil areas $(<1 \%)$ are less representative in the APA-Guaraqueçaba. Buffalo farms were common in the region in the 1970s and 1980s (FERRETI; BRITEZ, 2006). After that, the cattle breeding was abandoned and a large part of the region became protected area ("Federal APA" of Guaraqueçaba, "State APA" Guaraqueçaba, Guaraqueçaba Ecological Station, Superagui National Park and the Private Reserves of Natural Heritage Águas Belas, Salto Morato and Sebuí), where the agriculture ceased more than 10 years ago (GRISE et al., 2009). Despite few representatives in APA-Guaraqueçaba, exotic pastures can drastically change the ecosystems, by preventing seed arrival and germination and limiting forest succession (CHEUNG et al., 2009). Thus, conservation initiatives should take this into consideration for guaranteeing ecosystem resilience.

Slopes and lowlands are very distinctive landscapes in the APA-Guaraqueçaba. Slopes not only comprise a larger proportion of the area ( $67 \%$ of APAGuaraqueçaba area), but they are also more forested (Dense Ombrophilous Forest and secondary forest) and better preserved than lowlands (96.3 and $71.3 \%$ of the compartment area, respectively). The great

Revista Árvore, Viçosa-MG, v.36, n.5, p.961-970, 2012 
elevation in the "Serra do Mar" Mountain Range was one important barrier to anthropization in Atlantic Forest, where the largest remaining fragments are found (SANTOS et al., 2006, RIBEIRO et al., 2009). In the lowland region, farms for agriculture and cattle raising were more frequent in the 70's and 80's (FERRETI; BRITEZ, 2006). These historical differences resulted in a landscape dominated by much larger and more connected fragments in slopes compared to lowlands. Although the slopes have high environmental fragility, due to the steep slopes and the great potential for degradation (IPARDES, 2001), efforts to restore degraded
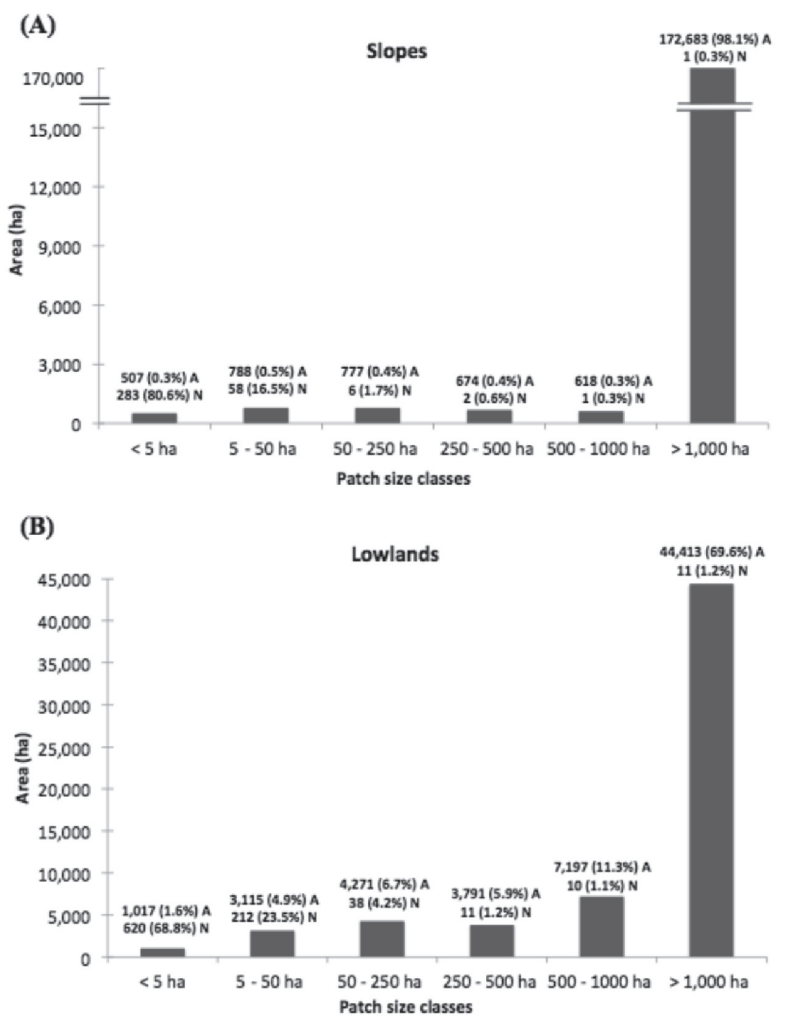

Figure 4 - Distribution of the number and area of Dense Ombrophilous Forest patches in the slopes (A) and lowlands (B) of APA-Guaraqueçaba, Paraná State, Brazil. A: Sum (and \%) of the areas of the patches in each class; N: Number of patches (and \%) in each class. Note that the scale is different in the two graphs.

Figura 4 - Distribuição do número e área de manchas de Floresta Ombrófila Densa nas encostas (A) e planícies (B) na APA de Guaraqueçaba, PR, Brasil. A: soma (e\%) das áreas das manchas em cada classe; $N$ : número de manchas (e\%) em cada uma das classes. Note que as escalas são diferentes entre os gráficos. ecosystems should be concentrated mainly on the lowlands, where there has been more anthropogenic disturbance.

Recent studies indicate that there are only $10 \%$ of the original Atlantic Forest lato sensu in the Paraná State (SOS MATA ATLÂNTICA; INPE, 2008), distributed mainly along the coast (FILA et al., 2009; VIDOLIN et al., 2011). In fact, there was little change in the land use and land cover in the northern coast of Paraná in the period between 1986 and 1999 and most of the changes occurred near existent highways (PROATLÂNTICA, 2001; SCHMIDLIN; BRITEZ, 2002).

\section{CONCLUSIONS}

Our results support previous descriptions that have been made for the region, showing that the Serra do Mar is indeed the most important fragment of the Atlantic Forest biome (RIBEIRO et al., 2009). Whereas other regions are important for conservation because of their high diversity levels (MARTINI et al., 2007), the northern coast of Paraná is probably one of the least fragmented areas, where efforts to maintain its preservation must be encouraged in order to guarantee the biodiversity conservation of the Atlantic Forest.

\section{ACKNOWLEDGEMENTS}

We are thankful to the Brazilian Research Council (CNPq) and to the NGO "Fundação Grupo Boticário" (FGB) for financial support; to NGO "Sociedade de Pesquisa em Vida Selvagem e Educação Ambiental" (SPVS) and Ricardo M. Britez for logistic support; to Giselda Durigan and Isabela Varassin, for suggestions on the first version of this manuscript. The second and the fourth authors received productivity grants from $\mathrm{CNPq}$.

\section{REFERENCES}

ALMEIDA, F. F. M.; CARNEIRO, C. D. R. Origem e Evolução da Serra do Mar. Revista Brasileira de Geociências, v.28, n.2, p.135-150, 1998.

BIGARELLA, J. J. Contribuição ao Estudo da Planície Litorânea do Estado do Paraná. Brazilian Archives of Biology and Technology, Jubilee Volume (1946-2001), p.65-110, 2001.

Revista Árvore, Viçosa-MG, v.36, n.5, p.961-970, 2012 
BIHN, J. H.; GEBAUER, G.; BRANDL, R. Loss of functional diversity of ant assemblages in secondary tropical forests. Ecology, v.91, p.782-792, 2010

BORGO, M. et al. Espécies arbóreas de um trecho de Floresta Atlântica do município de Antonina, Paraná, Brasil. Floresta, v.41, p.819-832, 2011.

BORSATTO, R. S. et al. Problemas agrários do litoral paranaense. Scientia Agraria, v.8, p.421-423, 2007.

BRASIL. Decreto n. 90.883, de 31 de janeiro de 1985. Dispõe sobre a implantação da Área de Proteção Ambiental de Guaraqueçaba. Diário Oficial da União, Brasília, 31 de jan. de 1985.

BRASIL. Portaria do Ministério do Meio Ambiente n. 150 de 17 de maio de 2006. Relator: Claudio Langone. Diário Oficial da União, Brasília, v.93, p. 71-73, 2006.

CALEGARI, L. et al. C.Análise da dinâmica de fragmentos florestais no município de Carandaí, MG, para fins de restauração florestal. Revista Árvore, v.34, n.5, PAGINAS, 2010.

CHEUNG, K. C.; MARQUES, M. C. M.; LIEBSCH, D. Relação entre a presença de vegetação herbácea e a regeneração natural de espécies lenhosas em pastagens abandonadas na Floresta Ombrófila Densa do Sul do Brasil. Acta botanica Brasilica, v.23, p.1048-1056, 2009.

DEAN, W. With broadax and firebrand: the destruction of the Brazilian atlantic forest. Berkeley: University of California Press, 1995.

EASTMAN, J. R. Idrisi Andes: Guide to GIS and Image Processing. Worcester: Clark University, 2006.

FERRETTI, A. R.; BRITEZ, R. M. Ecological restoration, carbon sequestration and biodiversity conservation: The experience of the Society for Wildlife Research and Environmental Education (SPVS) in the Atlantic Rain Forest of Southern Brazil. Journal for Nature Conservation, v.14, p.249-259, 2006.

Revista Árvore, Viçosa-MG, v.36, n.5, p.961-970, 2012
FILA, R.; VANZELA, A. L. L.; TOREZAN, J. M. D. Effectiveness of Paraná State conservation units system, South Brazil. Natureza \& Conservação, v.7, n.1, p.166-180, 2009.

FOODY, G. M. Status of land cover classification accuracy assessment. Remote Sensing and Environment, v. 80, n.1, p.185-201, 2002.

FONSECA, C. R.; et al. Towards an ecologically sustainable forestry in the Atlantic Forest.

Biological Conservation, v.142, n.1, p.12091219, 2009.

GALINDO-LEAL, C.; CÂMARA, I. G. Atlantic forest hotspot status: an overview. In:GALINDOLEAL, C.; CÂMARA, I. G., (Eds.) The Atlantic Forest of South America: biodiversity status, threats and outlook. Washington: CABS and Island Press, 2003. p.3-11.

GRISE, M. M. et al. A estrutura da paisagem do mosaico formado pelas unidades de conservação presentes no litoral norte do Paraná. Floresta, v.39, n.4, p.723-742, 2009.

GUAPYASSÚ, M. D. S. Caracterização fitossociológica de três fases sucessionais de uma floresta ombrófila densa submontana Morretes - Paraná. 165f. Dissertation (Master's Forest Sciences) - Setor de Ciências Agrárias, Universidade Federal do Paraná, Curitiba, 1994.

INSTITUTO BRASILEIRO DE GEOGRAFIA E ESTATISTICA - BGE. Manual técnico da vegetação brasileira. Rio de Janeiro: IBGE, 1992. (Série Manuais Técnicos em Geociências)

INSTITUTO NACIONAL DE PESQUISAS ESPACIAIS - INPE. Available at: http:// www.inpe.br/index.php, 2009.

IPARDES. Macrozoneamento da Área de Proteção Ambiental de Guaraqueçaba. Curitiba: Instituto Paranaense de Desenvolvimento Econômico e Social, 1990.

IPARDES. Zoneamento da Área de Proteção Ambiental de Guaraqueçaba. Curitiba: Instituto Paranaense de Desenvolvimento Econômico e Social, 2001. 120p. 
ITCG. Instituto de Terras Cartografia e Geociências do estado do Paraná. Available at: http://www.itcg.pr.gov.br/. 2009.

LANA, P. C. Novas formas de gestão dos manguezais brasileiros: a Baía de Paranaguá como estudo de caso. Desenvolvimento e Meio Ambiente, v.10, p.169-174, 2004.

LANG, S.; BLASCHKE, T. Análise da paisagem com SIG. São Paulo: Oficina de Textos, 2007.

LEITÃO, F. H. M.; MARQUES, M. C. M.; CECCON, E. Young restored forests increase seedling recruitment in abandoned pastures in the southern Atlantic Rainforest. Revista de Biología Tropical, v.58, n.4, p.12711282, 2010.

LIEBSCH, D.; GOLDENBERG, R.; MARQUES, M. C. M. Florística e estrutura de comunidades vegetais em uma cronoseqüência de Floresta Atlântica no Paraná. Acta Botanica Brasilica, v.21, n.4, p.983-992, 2007.

LIEBSCH, D.; MARQUES, M. C. M.; GOLDENBERG, R. How long does the Atlantic Rain Forest take to recover after a disturbance? Changes in species composition and ecological features during secondary succession.

Biological Conservation, v.141, n.6, p.17171725, 2008.

LOPES, A. V. et al. Long-term erosion of tree reproductive trait diversity in edge-dominated Atlantic forest fragments. Biological

Conservation, v.142, p.1154-1165, 2009.

MARQUES, M. C. M.; SWAINE, M. D.; LIEBSCH, D. Diversity distribution and floristic differentiation of the coastal lowland vegetation: implications for the conservation of the Brazilian Atlantic Forest.

Biodiversity and Conservation, v.20, n.1, p.153-168, 2011.

MARTINI, A. M. Z. et al. A hot-point within a hot-spot: a high diversity site in Brazil's Atlantic Forest. Biodiversity and Conservation, v.16, n.11, p.3111-3128, 2007.
METZGER, J. P. et al. Time-lag in biological responses to landscape changes in a highly dynamic Atlantic forest region. Biological Conservation, v.142, n.6, p.1166-1177, 2009.

MYERS, N., R. A. et al. Biodiversity hotspots for conservation priorities. Nature, v.403, p.853-845, 2000.

OLIVEIRA-FILHO A. T.; FONTES, M. A. L. Patterns of ûoristic differentiation among Atlantic Forests in Southeastern Brazil and the inûuence of climate. Biotropica, v.32, n.4b, p.793-781, 2000.

PARDINI, R. et al. The challenge of maintaining Atlantic forest biodiversity: A multi-taxa conservation assessment of specialist and generalist species in an agro-forestry mosaic in southern Bahia. Biological Conservation, v.142, n.6, p.1178-1190, 2009.

PROATLÂNTICA. Mapeamento da Floresta Atlântica do Estado do Paraná. Programa de proteção da floresta atlântica, Secretaria de Estado e do Meio Ambiente e Recursos Hídricos do Paraná, 2001.

RIBEIRO, M. C. et al. The Brazilian Atlantic Forest: How much is left, and how is the remaining forest distributed? Implications for conservation. Biological Conservation, v.142, n.6, p. 1141-1153, 2009.

RODERJAN, C. V. et al. As Unidades Fitogeográficas do Estado do Paraná. Ciência \& Ambiente, v.24, n.1, p.75-92, 2002.

SANTOS, L. J. C. et al. Mapeamento Geomorfológico do estado do Paraná. Revista Brasileira de Geomorfologia, v.7, n.2, p.3-12, 2006.

SCHMIDLIN, D.; BRITEZ R. M. Área de Proteção Ambiental APA de Guaraqueçaba: Estudo multitemporal de uso do solo. Curitiba: 2002. 38p. (Relatório Técnico)

SILVA, J. M. C.; CASTELETI, C. H. M. Status of the biodiversity of the Atlantic Forest of Brazil. In: GALINDO-LEAL, C.; CÂMARA, I. G., (Eds.). The Atlantic Forest of South America: biodiversity status, threats, and outlook. Washington: CABS and Island Press, 2003. p.43-59.

Revista Árvore, Viçosa-MG, v.36, n.5, p.961-970, 2012 
SOS MATA ATLÂNTICA, INSTITUTO

NACIONAL DE PESQUISAS ESPACIAIS. Atlas

dos remanescentes florestais da Mata

Atlântica, período de 2000 a 2005, 2008.

VIDOLIN, G. P.; BIONDI, D.; WANDEMBRUCK, A. Análise da estrutura da paisagem de um remanescente de floresta com Araucária,

Paraná, Brasil. Revista Árvore, v.35, n.3, p.515-525, 2011.
VIEIRA, M. V. et al. Land use vs. fragment size and isolation as determinants of small mammal composition and richness in Atlantic Forest remnants. Biological Conservation, v.142, n.6, p.1191-1200, 2009.

ZWIENER, V.; BIHN, J. H.; MARQUES, M. C. M. Ant-diaspore interactions during secondary succession in the Atlantic forest of Brazil. Revista de Biología Tropical, v.60, n.2, p.933-942, 2012. 